Volume 4 Nomor 1, Juni 2017, Hlm 69-86

Akses Online :

http:// jurnal.lp2msasbabel.ac.id

Dipublikasikan oleh :

Fakultas Tarbiyah IAIN Syaikh Abdurrahman Siddik Bangka Belitung

Info Artikel:

Diterima: 09/03/2017～Direvisi: 20/03/2017 01/06/2017

\title{
MEMAKNAI PENDIDIKAN DALAM HADITS NABI
}

\author{
SUBRI
}

IAIN Syaikh Abdurrahman Siddik Bangka Belitung

Email : puteriku_syika@yahoo.com

\begin{abstract}
Abstrak
Salah satu sumber hukum Islam yang penting dalam pembentukan hukum sesudah al-Qur'an adalah al-Hadits. Disamping itu, hadits juga mempunyai fungsi lain yaitu sebagai penjelas terhadap apa yang terkandung dalam al-Qur'an yang global. Merinci atau memberikan contoh pelaksanaannya. Dan sudah kita maklumi bersama, bahwa ketika Rasulullah wafat, beliau tidak meninggalkan apa-apa untuk umatnya kecuali al-Qur'an dan al-Hadits. Dengan dua sumber pengangan hidup tersebut, manusia akan selamat di dunia dan di akherat selama dijadikan lentera sepanjang hidupnya. Untuk dapat memahami keduanya dibutuhkan alat yaitu berupa ilmu pengetahuan sehingga dalam menelaah dan mengkaji keduanya tidak salah baca dan interpretasi. Dan ilmu pengetahuan diperoleh melalui proses pendidikan.
\end{abstract}

\begin{abstract}
One of the sources of Islamic law are important in the formation of the law after the Qur'an is al-Hadith. Besides that, the hadeeth also has another function, namely as explanatory of what is contained in the Qur'an that are global. Elaborate or give an example implementation. And already we understand together, that when the Prophet died, he did not leave anything for his people except al-Quran and al-Hadith. With two pengangan source of life, humans would survive in the world and in the hereafter for lanterns used throughout his life. To understand both needed a tool in the form of science that in reviewing and assessing the two are not misreading and interpretation. And the knowledge gained through the educational process.
\end{abstract}




\section{A. Pendahuluan}

Makhluk ciptaan Allah yang paling sempurna adalah manusia. Dengan bahasa lain bahwa manusia diciptakan oleh Allah SWT adalah mahluk yang sebaik-baik ciptaannya, karena manusia memiliki beberapa kelebihan. Di samping ia bisa berkomunikasi dengan sesamanya dan yang terpenting adalah manusia memiliki akal. Dengan akal inilah manusia bisa berpikir, membaca alam, menelaah dan bisa melakukan sebuah revolusi atau perubahan dalam hidup dan kehidupannya.

Manusia, dengan akal dapat berpikir, menganalisa, menelaah, membaca gejala dan fenomena bahkan dapat menembus alam lain dll dan dapat melakukan hal diluar yang tidak dapat dilakukan oleh makhluk ciptaan Allah lainnya, dan kemudian dengan akal ini juga bisa memilah dan memilih perbuatan yang baik (amalun Sholih) atau perbuatan-perbuatan jahat (a'maalun sayyi'ah). Proses ini berjalan sesuai denga takdirnya dan sesuai dengan keteraturan tanpa ada intervensi mahluk lainnya di alam ini, artinya bahwa akal tersebut bisa dijadikan kebaikan dan juga bisa membuat kerusakan bagi manuisa itu sendiri, tergantung kepada yang memiliki akal untuk membawa kemana peran akal itu di gunakan.

Di samping itu, agar kehidupan manusia dapat lebih baik dan berubah lebih baik lagi sehingga maksimal di dunia ini, maka manusia membutuhkan pendidikan, karena dengan pendidikan manusia bisa mendewasakan dirinya atau dengan kata lain pendidikan merupakan suatu upaya untuk memanusiakan manusia. Melalui pendidikan manusia dapat tumbuh dan berkembang secara wajar dan sempurna.

Pendidikan bisa merubah manusia dari tidak tahu menjadi tahu. Dari tidak baik menjadi baik. Pendidikan mengubah semuanya. Begitu pentingnya pendidikan dalam Islam sehingga merupakan suatu kewajiban perorangan. Rasulullah SAW. bersabda : "Menuntut ilmu itu diwajibkan atas tiap orang Islam" (HR. Ibnu Barri).

Disinilah kemudian, peran pendidikan dituntut dalam menegakkan dan mengarahkan kepada kebaikan dan jalan lurus (istiqamah). Pendidikan 
adalah tonggak utama dalam menciptakan manusia yang memiliki kepribadian yang baik, merubah sikap dari yang tidak baik menjadi baik, merubah karakter, tingkah laku dll. Sehingga peran pendidikan luar biasa bagi perkembangan hidup dan kehidupan umat manusia. Oleh karena itu, bagi pelaku dalam dunia pendidikan baik guru, dosen, ustadz / ustadzah maupun stake holder yang berkecimpung dalam dunia pendidikan harus memperhatikan dan merealisasi ekspektasi masyarakat bahwa melalui pendidikanlah generasi bangsa bisa maju dan berkembang dan pada implementasinya tetap berpijak teguh pada al-Qur'an dan al-Hadits.

Berpegang teguh pada al-Qur'an dan al-Hadits sehingga akal manusia dapat istiqamah/konsisten dalam belajar menuntut ilmu pengetahuan maupun belajar tentang kehidupan, dan belajar tersebut membutuhkan pendidikan dan pada akhirnya manusia memiliki ilmu pengetahuan. Dengan ilmu pengetahuan inilah manusia manusia menjadi mahluk Allah yang sempurna, namun kesempurnaan tersebut belumlah paripurna kalau tidak dibarengi dengan campur tangan agama. Agamalah yang menjadi rem untuk membatasi kebebasan suatu ilmu pengetahuan. Sebagai rem maka peran agama sangat urgen bagi manusia dengan ilmu pengetahuannya agar menjadi manusia yang paripurna selamat di dunia dan akherat.

Perlu diketahui bahwa kualitas tertinggi dari manusia yang berpengetahuan ditentukan oleh kadar takwanya. Takwa pada tingkatan tertinggi menunjukkan kepribadian manusia yang benar-benar utuh dan integral; semacam stabilitas yang terjadi setelah semua unsur yang positif diserap masuk ke dalam diri manusia. Di dalam takwa terdapat radar hati nurani yang melaluinya, manusia bisa membedakan mana yang benar dan salah, yang lurus dan sesat, dan akan melindungi (menjaga) dirinya dari perbuatan yang buruk dan jahat. Atas pengetahuan akan adanya sisi baik dan buruk, benar dan salah, serta lurus dan sesat itu manusia diberi kebebasan untuk memilih jalan yang dipilihnya. Dari sisi ini, manusia adalah makhluk yang merdeka. Namun demikian, di sisi yang lain manusia juga harus mempertanggungjawabkan setiap pilihan yang diambilnya kepada Allah di 
dunia dan akhirat nanti. Sebab kebebasan itu diberikan sebagai konsekuensi dari rahmat dan kepengasihan Allah kepada manusia. Dan Allah akan menilainya dengan alat ukur; takwa, baik untuk menilai manusia sebagai individu maupun sebagai anggota masyarakat.

Salah satu sumber hukum Islam yang penting dalam pembentukan hukum sesudah al-Qur'an adalah al-Hadits. Disamping itu, hadits juga mempunyai fungsi lain yaitu sebagai penjelas terhadap apa yang terkandung dalam al-Qur'an yang global. Merinci atau memberikan contoh pelaksanaannya. Dan sudah kita maklumi bersama, bahwa ketika Rasulullah wafat, beliau tidak meninggalkan apa-apa untuk umatnya kecuali al-Qur'an dan al-Hadits. Dengan dua sumber pengangan hidup tersebut, manusia akan selamat di dunia dan di akherat selama dijadikan lentera sepanjang hidupnya. Untuk dapat memahami keduanya dibutuhkan alat yaitu berupa ilmu pengetahuan sehingga dalam menelaah dan mengkaji keduanya tidak salah baca dan interpretasi. Oleh karenanya dalam tulisan ini mengangkat sebuah hadits Nabi yang berkaitan dengan ilmu dan pendidikan.

\section{B. Penelusuran Hadits}

Adapun hadits yang akan di takhrijkan dalam penulisan ini, sebagaimana yang diriwayatkan oleh Muawwiyah r.a., yaitu :

$$
\text { من برد الله به خير ا يفقهه في الدين (متفق عليه) }
$$

Yang artinya :

Dari Muawiyah r.a. bahwa Rasulullah saw. bersabda : "Barangsiapa yang dikehendaki oleh Allah kebaikan, maka Dia akan memberinya pemahaman tentang agama”. (Muttafaq Alaihi).

Hadits diatas dapat dilihat dalam buku terjemahan hadits Bulughul Maram karangan Ibnu Hajar Atsqalani, bab mendorong untuk berakhlak mulia halaman 497, hadits nomor 1551.

Hadits tersebut diatas adalah hadits shohih yang menempati hirarchi tingkatan pertama dalam syarat-syarat hadits shohih. Hadits ini dari 
Muawiyah (w. 60/680) "ia adalah satu di antara putra Abu Sufyan, seorang tokoh yang mengepalai perlawanan bangsa Makkah terhadap Nabi Muhammad. Muawiyah menjadi khlaifah Islam keenam dan merupakan pendiri dinasti setelah memaksa Hasan ibn Ali melepaskan jabatan khalifah". ${ }^{1}$

Merujuk pada matan hadits tersebut diatas, dapat disimpulkan bahwa hadits ini termasuk golongan hadits Makiyah. Hal ini sesuai dengan ayat alQur'an surat al-Ankabut Ayat 43 yang artinya Dan perumpamaanperumpamaan ini Kami buat untuk manusia; dan tiada yang memahaminya kecuali orang-orang yang berilmu. yang termasuk golongan surat-surat makiyah.

\section{Perawi (Mukhrij) Hadits Dan Biografinya}

Mukhrij hadits diatas adalah yang diriwayatkan oleh Muttafq Alaihi, hadits Muttafaq Alaihi adalah hadits yang disepakati keshohihannya oleh Bukhari dan Muslim, yang menempati urutan pertama dalam hirarchi hadits shohih. Berikut adalah biografi kedua perawi tersebut :

1. Imam Bukhori (13 Syawal $194 \mathrm{H}$ - 30 Ramadhan $256 \mathrm{H}$ )

Nama lengkapnya ialah Abu' Abdullah Muhammad ibn Ismail ibn Ibrahim ibn Mughirah ibn al-Ja'fi ibn Bardizbah al-Bukhari. Dia di kenal dengan Bukhari, hal ini di sandarkan pada tempat kelahirannya, yakni bukhara. Ayahnya bernama Ismail terkenal sebagai seorang ulama shaleh. ${ }^{2}$ Nenek moyang Bukhori adalah orang Parsi dan yang pertama masuk Islam ialah Jaddabiyah al-Mughirah melalui al-Yaman bin Ahnas al-Ja'fy, seorang Gubernur Bukhara, yang menjadi wali bagi Bukhari dan keturunannya.

Ketika usianya menginjak sepuluh tahun, dia selalu datang dan mempelajari ilmu hadits kepada al-dakhili, seorang ahli yang mahir dalam bidang tersebut. Setahun kemudian dia mulai menghafal hadits-hadits

\footnotetext{
${ }^{1}$ Cyril Glasse, Ensiklopedi Islam, (Jakarta : PT RajaGrafindo Persada), 1999, hlm 275.

2 Ending Soetri, Ilmu Hadits Kajian Riwayah \& Dirayah, (Bandung : Amal Bakti Press), 2000, hlm. 235.
} 
Nabi saw dan sudah berani mengoreksi kesalahan dari guru yang keliru yang keliru menyebutkan periwayatan hadits. Beliau telah menghafal hadits-hadits yang terdapat dalam kitab karangan al-Mubarak dan karangan Waqi' al-Jarrah, serta melawat ke berbagai kota untuk mendatangi ulama-ulama hadits.

Diantara kota yang pernah beliau kunjungi dalam rangka mencari ilmu hadits adalah : Maru, Naisaburi, Ray, Baghdad, Basrah, Kufah, Madinah, Mekkah, Mesir, Damaskus, dan Asqalani. Guru-gurunya dalam bidang hadits lebih dari 1000 orang. Beliau sendiri pernah menyebutkan bahwa kitab al-Jami' al-Saghir atau yang terkenal dengan nama Shahih alBukhari, disusun dari hasil menemui 1.080 orang guru dalam bidang ilmu hadits.

Beliau terkenal dengan kuat hafalannya, ketika masih kecil, sudah mampu menghafal 70.000 hadits lengkap dengan sanadnya. Mengetahui hari lahir, wafat dan tempat para perawi dan yang dihafalnya tersebut ia catat juga.

Imam al-Bukhari dilahirkan pada malam hari raya Ramadhan, tepatnya 13 Syawal tahun 194 Hijriyah, dan wafat pada hari sabtu di malam lebaran idul fitri 1 Syawal 256 Hijriyah atau bertepatan dengan tanggal 31 Agustus 870 Masehi.

2. Imam Muslim $(202 \mathrm{H}-261 \mathrm{H})$

Nama lengkapnya adalah Abu Husain Muslim ibn al-Hajjaj ibn Muslim al-Qusyairi al-Naisaburi. Beliau di nisbatkan kepada al-Naisaburi Karen lahir dan wafat di Naisabur. Imam al-Bukhari dan Muslim dalam rawi hadits disebutkan dengan Syaikhani (dua syaikh). ${ }^{3}$

Semenjak kecil, ketika umurnya menginjak 14 tahun, ia mulai mengkhususkan diri mencari dan mendengarkan hadits-hadits dari gurugurunya di Naisabur. Karena ketertariakannya dengan hadits, maka ia mengadakan rihlah ke beberapa tempat diantaranya Hijaz, Irak, Suriah dan

\footnotetext{
${ }^{3}$ Ibid., hlm 238
} 
Jurnal TARBAWY

Jurnal Pendidikan Islam
Volume 4 Nomor 1, Juni 2017

Akses Online: http:// jurnal.lp2msasbabel.ac.id

Mesir. Dalam perjalanannya ia bertemu dengan guru-guru dan ulamaulama hadits terkemuka dan pebgahafal-pengahafal hadits, dan ia pernah belajar dengan Imam Bukhari ketika beliau berkunjung di Naisabur. Dianatar guru-gurunya yang lain dan beliau pernah meriwayatkan hadits mereka adalah Yahya ibn Yahya al-Naisaburi, Ahmad ibn Hanbal, Ishaq ibn Rawaih, 'Abdullah ibn Maslamah, al-Qa'nabi, al-Bukhari dan lain sebagainya.

Para ulama sepakat menyatakan bahwa, kitab Muslim adalah kitab kedua setelah kitab al-Bukhari, dan tidak seorang pun yang dapat menyamai al-Bukhari dalam bidang mengkritik hadits sanad-sanad hadits dan perawi-perawinya selain dari Muslim. Imam Muslim lahir di Naisabur pada tahun 206 Hijiriyah dan wafat di Naisabur pul pada tahun 261 Hijriyah.

\section{Pemaknaan Hadits}

\section{Tinjauan Hadits}

Sebagaimana yang termaktub dalam hadits yang di sebutkan dalam pembahasan ini adalah, bahwa hadits ini menjelaskan bahwa "kefahaman tentang agama merupakan asas bagi segala kebaikan seorang muslim, baik menyangkut akhlak, perilaku atau amal perbuatan. Oleh karena itu, kita harus memberikan prioritas dan perhatian yang sangat besar terhadap upaya membentuk aspek kefahaman yang baik bagi setiap muslim tentang agamanya. Menyadari pentingnya masalah ini, Imam Syahid al-Banna menjadikannya sebagai syarat bai'at yang pertama dan utama“. 4

2. Hubungan Hadits dengan Ilmu dan Pendidikan

Merujuk pada matan hadits tersebut yang menceritakan tentang kebaikan yang diberikan Allah kepada hamba-Nya dengan jalan

\footnotetext{
${ }^{4}$ Yusuf Qardhawi, Muhammad Nashiruddin Al-Albani, Seleksi Hadits-Hadits Shahih tentang Targhib dan Tarhib, (Mesir : Darul Wafa' al-Manshuroh), 1993, hlm129.
} 
Jurnal TARBAWY

Jurnal Pendidikan Islam
Volume 4 Nomor 1, Juni 2017

Akses Online: http:// jurnal.lp2msasbabel.ac.id

menuntut dan mendalami ilmu-ilmu agama sehingga manusia diberi Allah pemahaman tentang agamanya. Menuntut ilmu adalah suatu kewajiban bagi muslim, dalam artian bahwa ilmu-ilmu yang bermanfaat dan membawa kemaslahatan dan manfaat bagi dirinya sendiri dan orang lain. Dengan ilmu derajat manusia bisa terangkat dan mulia seperti yang di ungkapkan dalam al-Qur'an surat al-Mujadalah ayat 11 yang artinya niscaya Allah akan meninggikan orang-orang yang beriman di antaramu dan orang-orang yang diberi ilmu pengetahuan beberapa derajat. Dan Allah Maha Mengetahui apa yang kamu kerjakan.

Senada dengan apa yang diungkapkan oleh Ibnu Taimiyah yaitu, "Tidak mungkin suatu perbuatan menjadi amal saleh jika orang yang melakukannya tidak berilmu dan paham atas apa yang ia lakukan". Pengertian ilmu yang dikemukakan oleh Ibu Taimiyah mencakup ilmu tentang kebaikan dan kemunkaran itu sendiri, yakni bisa membedakan antara keduanya dan berilmu tentang hal-hal yang diperintah dan yang dilarang oleh agama (Al-Quran dan hadits). Sedangkan Umar bin Abdul Aziz mengatakan, "Barangsiapa yang beribadah kepada Allah tanpa ilmu, maka apa yang dirusaknya lebih banyak dari apa yang diperbaikinya". lebih lanjut hadits Mu'adz Bin Jabal Rasulullah Saw bersabda, 'Ilmu adalah imam amalan, dan amalan mengikutinya.' Sesungguhnya niat dan amalan jika tidak berlandaskan ilmu maka itu adalah kebodohan, kesesatan dan mengikuti hawa nafsu...dan inilah perbedaan antara orang-orang jahiliyah dan orang-orang Islam,"

Kata "Kebaikan" dalam hadits ini adalah manivestasi dari ilmu, karena ilmu mendatangkan kebaikan bagi orang yang menuntutnya. Untuk memperoleh ilmu tentunya dengan proses pendidikan yang harus ditempuh oleh para penuntut ilmu. Dalam khazanah keilmuan dikenal dua istilah yang cukup populer yaitu pendidikan dan pengajaran. "pada umumnya

${ }^{5}$ Ibnu Taimiyah, al-Amru bil Ma'ruf wan Nahyu 'anil munkar, (Wizarah Syuun alIslamiyah), hlm 19 
pendidikan lebih menekankan pada aspek dalam diri manusia, sedangkan pengajaran lebih banyak bersentuhan dengan aspek luar". ${ }^{6}$ Lebih lanjut Zakiyah Deradjat menyebutkan ada tiga landasan utama dalam pendidikan Islam. Pertama : Al-Qur'an ${ }^{7}$, kedua : As-Sunnah ${ }^{8}$, ketiga : Ijtihad. ${ }^{9}$

Dalam kenyataannya, banyak orang yang berilmu, maka perilakunya akan baik, ahlaknya baik dan lebih tenang, dalam arti lain dalam menghadapi hidup ini tidak menjadi beban baginya, karena mereka tahu bahwa dengan ilmu hidup lebih mudah dan meyakinkan. Dalam kaitan inilah hadits tersebut menyatakan bahwa orang yang memiliki ilmu akan di beri Allah kebaikan, kebaikan dalam agamanya, hidupnya dan urusan dunianya.

Realitas kekinian, semakin berkembangnya ilmu pengetahuan yang ditandai dengan pesatnya tekhnologi dan meningginya kebutuhan hidup menjadikan manusia sekarang ini lupa bahkan melupakan tujuan sesungguhnya dari pemanfaatan ilmu pengetahuan tersebut. Tidak sedikit orang yang berilmu atau memiliki ilmu pengetahuan (orang pintar) namun perilakunya tidak mencerminkan seorang yang berilmu. Jarang sekali terlihat orang yang semakin tinggi ilmunya semakin rendah hati dan menghargai orang yang lebih rendah darinya. Dapat dilihat dari media televisi melalui acara talk show, diskusi, debat atau dalam acara lainnya yang menampilkan orang-orang pandai, orang-orang pintar berilmu pengetahuan tinggi akan tetapi kurang mengedepankan etika dan akhlak hlm 211.

${ }^{6}$ H.M. Suyudi, Pendidikan dalam Persepektif Al-Qur'an, (Yogyakarta : Mikraj), 2005,

${ }^{7}$ Al-Qur'an ialah firman Allah berupa wahyu yang disampaikan oleh Jibril kepada nabi Muhammad SAW, didalamnya terkandung ajaran pokok yang dapat dikembangkan untuk keperluan seluruh aspek kehidupan melalui ijtihad.

${ }^{8}$ As-Sunnah ialah perkataan, perbuatan ataupun pengakuan Rasul Allah SWT. Yang dimaksud dengan pengakuan ialah kejadian atau perbuatan orang lain yang diketahui Rasulullah dan beliau membiarkan saja kejadian atau perbuatan itu berjalan. Sunnah merupakan sumber ajaran kedua sesudah Al-Qur'an, seperti Al-Qur'an, Sunnah juga berisi aqidah dan syari'ah. Sunnah berisi petunjuk (pedoman) untuk kemaslahatan hidup manusia dalam segala aspeknya, untuk membina umat menjadi manusia seutuhnya atau muslim yang bertakwa.

${ }^{9}$ Ijtihad adalah istilah para fuqaha, yaitu berpikir dengan menggunakan seluruh ilmu yang dimiliki oleh ilmuwan syari'at Islam untuk menetapkan/menentukan sesuatu hukum syari'at Islam dalam hal-hal yang ternyata belum ditegaskan hukumnya oleh Al-Qur'an dan Sunnah. 
dalam berbicara, adu argumentasi, menjelekkan lawan bicara bahkan menuduh lawan bicara. Hal seperti ini tidak jarang didengar dan dilihat. Inilah potret manusia zaman sekarang yang haus akan kekayaan, jabatan, pujian bahkan haus akan dunia yang fana ini.

Tuntunan Rasulullah SAW melalui hadits-Nya tidak seperti gambaran tersebut diatas. Banyak sekali hadits-hadits Rasulullah SAW mengajarkan kepada manusia dalam berprilaku yang baik, bertutur kata dengan lemah lembut, tidak menjelek-jelekkan orang lain, bersikap rendah hati, menghargai orang yang lebih rendah baik dalam harta, ilmu dan kehidupan. Apakah ada yang salah dengan kehidupan manusia hari ini, apakah ada yang salah dengan pendidikan manusia hari ini, apakah kesalahan itu ada pada tenaga pendidik, format pendidikan bahkan tujuan pendidikan manusia hari ini. disinilah kemudian hadits memaknai pendidikan bahwa barang siapa menghendaki kebaikan maka ia harus menuntut ilmu, menggunakan ilmu pengetahuan tersebut untuk kebaikan dirinya, keluarganya, kehidupannya agar selamat dunia dan akherat. Inilah makna hadits Rasulullah SAW yang berbunyi;

$$
\text { من يرد الله به خير ا يفقهه في الدين (منفق عليه) }
$$

"Barangsiapa yang menghendaki kebaikan dari Allah, maka baginya agar memperdalam ilmu pengetahuan tentang agama”. (Muttafaq Alaihi).

Untuk memperoleh kebaikan tersebut tentunya dimulai dari keluarga bahwa jika pendidikan dalam keluarga baik akan membawa kebaikan kepada masyarakat sekitar bahkan secara menyeluruh akan membawa kebaikan pada bangsa. Menurut Hasan Langgulung, pendidikan dapat dilihat dari dua sudut pandang, yaitu sudut pandang individu dan sudut pandang masyarakat. Dari sudut pandang individu, pendidikan merupakan usaha untuk mengembangkan potensi-potensi individu yang terpendam dan tersembunyi. Sedangkan dari sudut pandang masyarakat, pendidikan merupakan usaha untuk mewariskan nilai-nilai budaya oleh generasi tua kepada generasi muda agar hidup masyarakat tetap 
Jurnal TARBAWY

Jurnal Pendidikan Islam
Volume 4 Nomor 1, Juni 2017

Akses Online: http:// jurnal.lp2msasbabel.ac.id

berkelanjutan. ${ }^{10}$ Dalam perspektif Islam, terdapat tiga term yang sangat erat berhubungan dengan makna pendidikan ini. Pertama, Ta'lim, berasal dari 'allama yang berarti mengajarkan. Atau sekedar memberitahu atau memberi pengetahuan. Kedua, Tarbiyah, mengandung arti memelihara, membesarkan dan mendidik, termasuk di dalamnya makna mengajar atau 'allama. Dari makna ini pendidikan dirumuskan sebagai proses bimbingan terhadap potensi manusia (jasmani, ruh dan akal) secara maksimal agar dapat menjadi bekal dalam menghadapi kehidupan dalam masa depan. Ketiga, Ta'dib, dari kata addaba yang mengandung makna ta'lim dan tarbiyah. Dalam pengertian ini pendidikan dirumuskan sebagai upaya membentuk manusia dalam menempatkan potensinya yang sesuai dengan susunan masyarakat, bertingkah laku secara proporsional dan cocok dengan ilmu serta tekhnologi yang dikuasainya.

1. Pendidikan bagi keluarga

Keluarga sebagai lembaga (institusi) sosial pertama dan juga lembaga pendidikan pertama yang merupakan pondasi dan asas untuk terbentuknya masyarakat yang bermoral berawal dari keluarga yang bermoral. Sedang pendidikan Islam bertujuan untuk mewujudkan manusia bermoral yakni insan kamil yang bertakwa.

Pendidikan dalam keluarga memerlukan keteladanan dari orangorang yang menjadi figur di dalam keluarga. Sedangkan untuk menjadi teladan, seseorang mesti mendidik dirinya sendiri. Dengan keteladanan, pendidikan akan lebih efektif daripada hanya dengan perintah maupun ucapan dengan lisan. Sebab itu, Allah swt tidak suka kepada orang yang hanya berkata saja tanpa berbuat. Allah swt berfirman :" Hai orang-orang yang beriman, mengapa kamu mengatakan apa yang tidak kamu perbuat ? amat besar kebencian di 1988), hlm.3.

${ }^{10}$ Hasan Langgulung, Asas-Asas Pendidikan Islam, Cet. II, (Jakarta: Pustaka Al-Husna, 
sisi Allah bahwa kamu mengatakan apa-apa yang tidak kamu kerjakan."11

Dapat dipahami bahwa, faktor utama pendidikan dalam keluarga adalah pendidikan keteladanan dari seluruh anggota keluarga yang di aplikasikan dan realisasikan secara nyata pada setiap aspek kehidupan berkeluarga. Dengan demikian sentral pendidikan adalah keluarga dan menjadi tanggung jawab anggota keluarga secara keseluruhan tidak terbatas hanya orang tua saja. Sesuai dengan porsi dalam status dan kedudukannya masing-masing bertanggung jawab atas perbuatannya untuk mewujudkan pendidikan.

\section{Pendidikan bagi orang tua}

Pendidikan bagi orang tua adalah hal-hal yang menjadi tanggung jawab orang tua untuk diupayakan menyangkut hubungannya dengan anak-anaknya. Tanggung jawab orang tua terhadap anak, merupakan hak anak atas orang tuanya. Didalam kitab Al-Ahwal Al-Syahshiyah, Muhammad Abu Zahrah menguraikan hakhak anak tersebut, sebagian menjadi kewajiban ayah, sebagian menjadi kewajiban ibu dan lainnya menjadi kewajiban orang tua bersama (ayah dan ibu).

Selanjutnya Ahmad Faiz menyatakan, ayah dan ibu mempunyai saham yang sama dalam menyiapkan bibit unggul penerus mereka. Akan tetapi ibu mempunyai peran yang lebih penting dan determenin dalam menyiapkan anak-anak. Pada tahap persiapan saja, peran ibu merentang hingga sembilan bulan. Dalam jangka sembilan bulan ini, janin mengonsumsi materi kimiawi yang dihisapnya dari darah ibunya melalui plasenta. Pada masa-masa ini sang ibu kadang seperti mabuk dengan janinnya. Kondisi pisik dan kejiwaan yang matang setelah satu atau dua kali hamil. Perempuan yang belum pernah melahirkan, kondisi kejiwaannya belum matang, umumnya lebih emosional. Tugas

${ }^{11}$ QS. Ash-Shaff (61) : 2-3. 
dan fungsi ini ditempuh untuk kesempurnaan dan kematangan kaum wanita sebagai ibu. ${ }^{12}$ Di dalam mengasuh dan mendidik, orang tua diwajibkan berlaku adil terhadap anak-anak. Hal ini digambarkan dalam kisah Yusuf a.s. kecemburuan akan ketidakadilan orang tua akan menumbuhkan kebencian anak-anak yang lain.

Pada akhirnya adalah peran orang tua sangat penting sekali dalam membimbing dan mendidik anak. Untuk menjalani keduanya, tentunya selaku orang tua harus mengerti dan memahami unsur-unsur dan pola-pola yang harus diberikan kepada anak-anak agar pendidikan yang diberikan lebih mudah dan terarah. Untuk mewujudkan harapan tersebut, orang tua harus rajin untuk mengisi diri dengan membaca, berbagi pengalaman dengan lainnya serta memberikan ruang waktu untuk mengikuti berbagai pelatihan mengenai perkembangan dan kemajuan anak.

3. Pendidikan bagi anak

Sesungguhnya anak adalah anugerah Allah yang amat berharga dan besar nilainya. Mereka adalah anugerah Allah swt. yang perlu dididik dan diasuh, tetapi kadang kala banyak orang tua lupa akan kewajiban ini. Memang, dalam mengasuh dan mendidik anak memerlukan banyak pengorbanan, kegigihan serta kesabaran yang tinggi.

Seperti diungkapkan diatas bahwa anak adalah amanah yang harus diperlakukan dengan sebaik mungkin agar menjadi penerus yang sholih, cerdas dan menjadi generasi yang bermanfaat. Tentunya untuk mewujudkannya perlu kiranya mengikuti panduan-panduan, Irman Noorhafituddin Dimyati, mengungkapkan lima panduan utama dalam mendidik anak-anak, yaitu :

a. Senantiasa mendo'akan kesejahteraan anak-anak mereka.

b. Membudayakan anak-anak dengan ilmu pengetahuan.

${ }^{12}$ Ahmad Faiz, Dustur Al-Usrah, hlm. 163 
Surnal TARBAWY

Jurnal Pendidikan Islam
Volume 4 Nomor 1, Juni 2017

Akses Online: http:// jurnal.lp2msasbabel.ac.id

c. Mendisiplinkan anak-anak dengan hidup sehat dan sempurna.

d. Meningkatkan pengetahuan kita sepanjang masa.

e. Menjadikan diri kita sebagai contoh terbaik buat anak-anak. ${ }^{13}$

Kemudian yang dimaksud dengan pendidikan bagi anak disini adalah hal-hal yang menjadi tanggung jawabnya untuk diupayakan menyangkut hubungannya dengan orang tuanya. ${ }^{14}$

Secara umum hubungan anak dan orang tua dalam konsep keluarga Islam struktural maupun fungsional saling melengkapi. Anak dan orang tua mempunyai kewajiban bersama untuk saling mengurus. Orang tua mengurus anak sampai dewasa atau menikah, dan anak setelah memiliki kemampuan berganti mengurus orang tua sampai meninggal. Hubungan timbal balik ini tentunya tidak akan terlepas sepanjang kehidupan anak manusia di dunia ini. Anak seharusnya lebih mengerti posisinya dan kewajibannya terhadap orang tua yang telah mendidik, pendek kata peran orang tua dalam membesarkan anaknya adalah satu perbuatan yang mustahil bisa tergantikan.

Kemudian apakah ada pengaruhnya keluarga dengan pendidikan, Pengaruh keluarga terhadap kepribadian anak tidak diragukan lagi, meskipun dalam ukuran relatif. Demikian pula, jika dikatakan keluarga merupakan lokasi terselenggaranya pendidikan, semua orang mafhum. Namun meskipun demikian perlu ditegaskan, pengaruh edukatif keluarga tidak hanya terdapat pada anak kecil, melainkan juga pada seluruh anggota keluarga, termasuk anak yang sudah bersekolah, pemuda yang masih tinggal bersama keluarga, dan orang dewasa (orangtua, ayah, ibu) sendiri yang menjadi pemimpin keluarga itu. Bahkan, mungkin juga orang lain yang berada di luar lingkungan keluarga. Di pihak lain, anak dan anggota keluarga lainnya

${ }^{13}$ Irman Noorhafituddin Dimyati, Membangun Ketahanan Keluarga, (Bandung: PT. Remaja Rosdakarya, 2007), hlm. 21.

${ }^{14}$ Mantep Miharso, Pendidikan Keluarga Qur'ani, (Yogyakarta, Safrina Insania Press, 2004), hlm. 123 
Jurnal TARBAWY

Jurnal Pendidikan Islam
Volume 4 Nomor 1, Juni 2017

Akses Online: http:// jurnal.lp2msasbabel.ac.id

tidak hanya mendapat pengaruh edukatif dari dalam keluarga bersangkutan melainkan juga dari luar. Mungkin betul, pada tahap awal perkembangannya, seorang anak terutama mendapat pendidikan dari lingkungan keluarganya, karena menurut pendapat itu, pembentukan kepribadian seseorang berlangsung pada usia balita.

Hal itu menegaskan, keluarga memegang peran penting dalam proses pendidikan dan pembinaan serta pembentukan jiwa dan kepribadian anak-anak. Karena itu, menurut Makkulau (1988), untuk menghasilkan anak-anak yang andal di masa depan perlu sekali diterapkan secara tepat pendidikan budi pekerti, agama dan etika, di samping pendidikan berpikir di dalam lingkungan keluarga. Jenis pendidikan tersebut seyogianya dimulai sejak dini (balita) melalui pendidikan informal di lingkungan keluarga. Keluarga diharapkan dapat memberikan peluang dan kesempatan kepada anak-anaknya untuk menginternalisasi nilai etika dalam rangka proses pembentukan konsep dirinya (self concept) yang positif. Keteladanan dan kepemimpinan orangtua sangat menentukan. Dengan kata lain, pembentukan kepribadian anak tergantung dari kualitas sebuah keluarga, sebagaimana pula pembentukan kepribadian bangsa yang harus dimulai dari pembangunan keluarga.

Faktor lain lingkungan keluarga yang berhubungan dengan perkembangan kognitif dan kemampuan intelektual anak adalah model pendidikan yang diterapkan, dan tersedianya perlengkapan atau fasilitas hidup dalam keluarga dan rumah tangga. Pertama, model pendidikan. Ada tiga model pendidikan yang bisa dikembangkan dalam keluarga, yakni model mekanis, organis dan proses. Dalam model mekanis, pendidikan adalah upaya untuk memberikan kemampuan untuk menyesuaikan diri kepada keadaan yang diasumsikan telah mantap. Dalam model organis, konsep yang paling menonjol adalah homeostasis yang melukiskan penyesuaian diri kepada lingkungan yang berubah, tetapi tanpa disertai perubahan pada 
struktur internal. Jadi, menurut model ini, pendidikan merupakan upaya memberikan kemampuan untuk menyesuaikan diri sambil mempertahankan struktur masyarakat yang ada.Sedangkan model ketiga yang lebih progresif, menggambarkan perubahan pada struktur sesuai keperluan dalam menghadapi situasi lingkungan yang berubah. Menurut model ini, pendidikan merupakan upaya untuk mengembangkan daya nalar dan kreativitas untuk kalau perlu mengubah struktur internal sesuai tuntutan situasi yang berubah dengan pesat, bahkan untuk mengendalikan perubahan itu sendiri.

Apabila model mekanis menekankan pada dominasi faktor luar terhadap perkembangan individu, maka model proses lebih menekankan pada pemberian kesempatan yang sangat leluasa kepada individu untuk mengembangkan potensi yang dimilikinya. Kedua, kualitas perlengkapan, terutama yang berhubungan dengan fasilitas untuk belajar di rumah berbeda-beda menurut status sosial. Secara umum, perlengkapan dan fasilitas belajar yang tersedia pada keluarga lapisan ekonomi rendah kurang baik dibanding dengan yang dimiliki keluarga lapisan menengah dan atas. Pemilikan dan pemanfaatan pesawat televisi serta media massa lainnya seperti koran dan majalah, di masyarakat masih berbeda menurut strata sosial. Demikian pula sarana hiburan keluarga seperti olahraga, musik, kendaraan atau fasilitas untuk melakukan perjalanaan guna memperoleh tambahan pengetahuan dan pengalaman, serta alat mainan terutama bernilai edukatif yang disediakan untuk anak-anak. Demikianlah, keluarga mempunyai potensi sebagai peletak dasar perkembangan aspek kognitif, apektif dan psikomotorik anak melalui proses pengasuhan, interaksi dan komunikasi. Apa yang dicapai dalam lingkungan keluarga akan langsung kelihatan pada tingkat pencapaian anak di lingkungan pendidikan formal di sekolah. Akan tetapi potensi ini tidak selalu dimanfaatkan dalam kehidupan sehari-hari, bahkan banyak keluarga yang tidak menyadarinya. 


\section{F. Penutup}

Sebagai penutup dari makalah ini, dapat saya ringkas pengertian dari hadits diatas sebelumnya adalah bahwa :

1. Dengan ilmu sesungguhnya Allah swt memberikan kebaikan berupa ; kebaikan ahklak, kebaikan perilaku / amal perbuatan, kebaikan hidup, ekonomi, pekerjaan, keturunan dll

2. Hadits tersebut diatas adalah hadits shohih yang menempati hirarchi pertama hadits shohih karena hadits tersebut diriwayatkan oleh Muttafaqun Alaihi (Bukhori \& Muslim)

3. Ilmu yang berlandaskan agama akan memberi kebaikan bagi tuannya, baik di dunia maupun di akherat dan Allah akan memberi kebaikan padanya berupa pemahaman tentang agama..

4. Barangsiapa yang beribadah kepada Allah tanpa ilmu, maka apa yang dirusaknya lebih banyak dari apa yang diperbaikinya

5. Ilmu adalah imam amalan, dan amalan mengikutinya.' Sesungguhnya niat dan amalan jika tidak berlandaskan ilmu maka itu adalah kebodohan

\section{Referensi}

Suyudi, M, Pendidikan dalam Perspektif Al-Qur'an, (Yogyakarta : Penerbit Mikraj), 1999

Soetrari, Endang, Ilmu Hadits Kajian Riwayah \& Dirayah, (Bandung : Amal Bakti Press), 2000

Atsqalani, Hajar, Ibnu, Alih Bahasa, Masdar Helmy, Tarjamah Hadits Bulughul Maram, Cet. Ketiga (Bandung : Gema Risalah Press), 1994

Kumpulan Makalah Studi Ilmu Hadits, PPS MSI UII, 2002/2003

Qardhawi, Yusuf., Seleksi Hadits-Hadits Shahih Tentang Targhib Dan Tarhib, Cet. Kedua (Mesir : Darul Wafa’ al-Manshuroh), 1993.

Deradjat, Zakiyah dkk, Ilmu Pendidikan Islam, Cet, Ketiga (Jakarta : Bumi Aksara), 1996 